\title{
A participatory discourse analysis of service users' accounts of staffed meeting places in Norwegian community mental health care
}

\author{
Lill Susann Ynnesdal Haugen* \\ Department of Psychosocial Science \\ University of Bergen, Norway \\ Email: lill.haugen@uib.no \\ *corresponding author
}

\section{Andreas Envy}

Department of Psychosocial Science

University of Bergen, Norway

Email: andreasnv@hotmail.com

\section{Tor-Johan Ekeland}

Faculty of Social Science and History

Volda University College, Norway

Email: tje@hivolda.no

\section{Marit Borg}

Faculty of Health Sciences

University College of Southeast Norway, Norway

Email: marit.borg@usn.no

\section{Norman Anderssen}

Department of Psychosocial Science

University of Bergen, Norway

Research Unit for General Practice, Uni Research Health,

Bergen, Norway

Email: norman.anderssen@uib.no

\begin{abstract}
Since the 1960s, deinstitutionalisation has been salient in mental health reforms across the West. In Norway, this culminated in the National Action Plan for Mental Health (19992008), where meeting places in community mental health care were deemed a prioritised strategy to counter social isolation among people in psychosocial hardships. However, during the same period in England, meeting places were beginning to be contested for
\end{abstract}


contributing to social exclusion. This is an inquiry of meeting places in Norway guided by the following research question: How do service users discuss their encounters with the spaces and people of meeting places? Situated in community psychology and participatory research traditions, we engaged in a participatory discourse analysis of four focus group discussions with 22 service users from meeting places. We detail and discuss four central discursive constructions of meeting places against the backdrop of a civil society identified as fraught with sanism that stigmatises and excludes service users: a compensatory public welfare arrangement positioning service users as citizens with social rights; a peer community positioning service users as peers who share common identities and interests; spaces of compassion validating service users as fellow human beings who are precious in their own right; and greenhouses facilitating service users to expand their horizons of possibility. This inquiry implies that meeting places could mean everything to the people who attend them by facilitating opportunities considered less accessible elsewhere in their everyday lives in a sanist civil society.

Keywords: Participatory research; community mental health care; mental health day centres; discourse analysis; service users; sanism; social democratic welfare state

\section{Introduction}

Since the 1960s, deinstitutionalisation and the building of community mental health care have been salient in mental health reforms across the West following several hundreds of years of exclusion from civil society (Bachke \& Larsen, 2017; Foucault, 1961/1988; Hamre, Fristrup, \& Christensen, 2016; LeFrancois, Menzies, \& Reaume, 2013). By the mid-1990s, the Norwegian Council for Mental Health (1995) had concluded that people with psychosocial hardships were still among the most neglected groups of the welfare state. Since 1999, the Norwegian National Action Plan for Mental Health (1999-2008) (Ministry of Health and Care Services, 1998) has been described as advocating a new direction for the everyday lives of people in psychosocial hardships through such efforts as strengthening community mental health care and the rights to citizenship of the social group administratively called 'mental health service users' (Bergem \& Ekeland, 2006).

The focus of this article is one of the prioritised areas of the Action Plan intended to counter social isolation and exclusion: meeting places ('day centres') in community mental health care (treffsteder/dagsenter) (Ministry of Health and Care Services, 1998). Norwegian meeting places could be described as daytime and sometimes evening spaces where people in psychosocial hardships can spend their days with peers and professional staff on an easyaccess volunteer basis, participate in diverse activities located inside and/or outside of dedicated houses or apartments and share meals and coffee at fair prices.

While meeting places were being prioritised in Norway, the community mental health care politics in England of the early 2000s included a national assessment that concluded that meeting places appeared to be undereffective at achieving the assessment's targets of increased participation in the labour market and mainstream services and, thus, by implication, contributed to social exclusion (Social Exclusion Unit, 2004). Such problematisations of meeting places constitute the background for discussing findings from the present analyses. Additionally, a Cochrane review of meeting places ('mental health day centres') did not find adequate randomised controlled trials, leading the authors 
to assert that compelling evidence for the continued provision of meeting places was lacking (Catty, Burns, Comas, \& Pool, 2008). Following the National Social Inclusion Programme (2008) and economic recessions, meeting places and other community-based services have been reported to be shrinking across the United Kingdom (Mattheys, 2015). More recently, shrinking services have also been documented in relation to a modernisation reform in the Swedish community mental health sector (Andersson, Eklund, Sandlund, \& Markström, 2016).

Meeting places have been described as valued and favoured by people attending them (e.g., Bachke \& Larsen, 2017; Bryant, 2011; Eklund \& Tjörnstrand, 2013; Larsen \& Topor, 2017). In several inquiries, meeting places generally appear to be portrayed as being among a select few publicly available spaces where the people attending them can go and be together with other people during the daytime, outside of the private sphere (e.g., Argentzell, Leufstadius, \& Eklund, 2012; Bryant, Craik, and McKay, 2004; Elstad \& Eide, 2009; Pinford, 2000). The favouring of meeting places appears related to the systematic exclusion and subjugation that people labelled with mental health problems encounter in society. Such exclusion is conceptualised as sanism or mentalism in the emerging field of Mad studies, which is concerned with explorations of the history, colonisation, culture, human diversity and knowledge of Mad people (LeFrancois et al., 2013). The concept of sanism entails that 'sanity' is considered normal and right in society while being viewed as psychosocially different is automatically considered pathological and bad (LeFrancois et al., 2013). The consequences of sanism are, thus, that psychosocially different people experience systematic under-privileging in society. The extent of sanist exclusion is well-documented across most domains and includes systematic barriers to accessing sustainable employment (EvansLacko, Knapp, McCrone, Thornicroft, \& Mojtabai, 2013; Social Exclusion Unit, 2004). Thus, less expendable income causes public spaces of commerce (e.g., cafes) to also become less accessible.

From a participatory research tradition within community psychology and based on discourse analysis, this article focuses on service users' first-hand knowledge and accounts of meeting places, generated through four focus group discussions. The following research question guided our inquiry: How do service users discuss their encounters with the spaces and people of meeting places?

\section{Staffed meeting places in Norway}

Guidelines from the Norwegian Directorate of Health (2005, pp. 25-27) emphasise the facilitation of diverse meeting places tailored to local contexts and needs that promote ideals, such as social equality, service user involvement, community, validation/recognition and self-determined development. Such diversity is also discussed in the reviewed literature (e.g., Bachke \& Larsen, 2017; Bryant, 2011).

Meeting places often operate as easy-access drop-in centres, although some require a first-time referral. The universal principle of the Nordic social democratic welfare states prescribes that health and welfare services, such as meeting places, should be available to citizens based on need (Brandal, Bratberg, \& Thorsen, 2013). The social democratic discourse, which gained democratic momentum in the Nordic countries over the twentieth century, is constituted of basic beliefs in redistributive justice through, for instance, taxation to compensate for unavoidable social inequalities and to promote human welfare through institutionalised solidarity (Brandal et al., 2013). Most meeting 
places appear to be provided by the municipal level of the welfare state, with some operated by third-sector non-governmental organisations (NGOs) (Kalseth, Pettersen, \& Kalseth, 2008).

Meeting places are not required by law, and they may be vulnerable to political and economic changes (Andersson et al., 2016). For instance, during the 2008 evaluation of the Action Plan funding period, meeting places were reported to be the second most used municipal community mental health service in Norway, covering over $90 \%$ of the 428 municipalities at the time (Kalseth et al., 2008). Shortly thereafter, the number of municipalities that reported having a meeting place dropped to below $80 \%$ (Osborg Ose \& Slettebak, 2012).

Neoliberalism has been on the rise in the Nordic countries (Hedegaard, 2016). In short, following central neoliberal ideals, welfare arrangements that were originally politically designed to compensate for social inequalities in civil society (Brandal et al., 2013) are often portrayed as state interventions that hinder 'freedom of choice' and 'free markets' unburdened by state regulation (Fine, 2012; Harvey, 2005; Hedegaard, 2016). A prospective case study in a Swedish city found few indications that the 'freedom of choice' reform implemented in the 2010s had benefited service users in meeting places (Andersson et al., 2016; Fjellfeldt, Eklund, Sandlund, \& Markström, 2016). On the contrary, it reported on changes such as reductions in time allowances for attending the service, satisfaction and staffing levels, as well as increases in administration, cutbacks and concerns for the future. As addressed in this case study, targets and outcomes of the reforms resonate with the market logic of new public management (NPM) (Fjellfeldt et al., 2016). NPM draws on neoliberalism (Harvey, 2005), and the main logic is to model the public sector to operate in line with market mechanisms to increase cost efficiency and productivity (Ekeland, Stefansen, \& Steinstø, 2011). A business that fails to operate costefficiently will eventually close down, which could also be the fate of underperforming public services in line with neoliberalism.

\section{Theoretical and methodological lenses}

With bases in critical branches of community psychology (e.g., Nelson, Prilleltensky, \& MacGillivary, 2001), participatory research traditions related to service user involvement (Borg \& Kristiansen, 2009) and discourse analysis (Parker, 2014/1992), we accompany Mad-identified scholars (e.g., LeFrancois et al., 2013) in the struggle against a history of exclusion (Foucault, 1961/1988). We hold that listening to current or former service users as legitimised knowers entails sophisticated, nuanced and robust knowledge maps over complex social terrains (e.g., Brydon-Miller, Kral, Maguire, Noffke, \& Sabhlok, 2011). Moreover, in agreement with critical scholars, we believe that it is increasingly vital to listen to the knowledge of the people who bear the ever-growing toll of social inequalities in the era of the neoliberal deregulation of welfare states and safety nets, both on empirical and ethical grounds (e.g., Dencker-Larsen \& Lundberg, 2016; Fine, 2012). Adhering to Parker's (2014 /1992, p. 5) Foucauldian working definition, we understand discourses as statements that make up systems that generate certain objects and position subjects. In line with Parker, our underlying interest is in the practical and real-life consequences that discourses make possible and generate.

\section{Methodology}

This article is part of a project aimed at exploring and illuminating meeting places in Norwegian community mental health care from a participatory

NJSR - Nordic Journal of Social Research 
community psychological perspective. As a team of co-researchers with firsthand knowledge of hardships and service use, as well as academic researchers from the fields of community psychology, social psychology and community mental health care, we co-produced this research project from the outset in 2012. Initially, 10 persons with first-hand knowledge of psychological hardship and meeting places volunteered to participate in a collaborative research process. The full team developed the research topic of 'meeting places'. Later, three of the co-researchers participated in one or more of the following phases: conducting the focus group interviews, taking part in important parts of the analysis, disseminating knowledge by communicating with the municipalities that were involved and by co-authoring publications. While the present analysis is based on focus group interviews with service users of staffed meeting places, another report from the project is based on focus group interviews with members of staff from several staffed meeting places (Ynnesdal Haugen, Envy, Borg, Ekeland, \& Anderssen, 2016).

Here, we centre on the first-hand knowledge of service users based on four separate focus group interviews. Guided by the work of psychologist lan Parker (2014/1992), we engaged in a participatory discourse analysis.

\section{Recruitment and participants}

With assistance from the municipalities and NGOs providing the meeting places in our selected region of western Norway, the first and second authors visited roughly 10 meeting places in the fall of 2013 to recruit a variety of persons attending different meeting places. Twenty-two participants volunteered to participate and provided their explicit informed consents. Ethical approval for the project was obtained from the Norwegian Social Science Data Service, the Data Protection Official for Research (project reference number: 33810/3/KH).

Approximately half of the participants typically attended meeting places in suburban or rural municipalities, while the remainder attended meeting places in a city municipality. The participants were six men and 16 women, aged between 27 and 67 years, with a majority being over 50 years. First visits to a meeting place occurred between 1985 and 2011, with the majority after the year 2000. Not all, but many, participants stated that they had been in contact with other mental health services from less than a year to 15 years or more. While many reported being home when not at the meeting place, some also reported spending time with family and friends, exercising, attending church and cafes and engaging in paid and voluntary work.

\section{Focus group discussions}

Focus group interviews could be considered advantageous in facilitating discussions about shared but variable aspects of everyday life among persons from different places (Malterud, 2012), which was relevant to this inquiry. We arranged four focus groups in agreed-upon locations, with each group comprising participants from two to five meeting places. The first and second authors moderated the focus groups, which lasted approximately 90 minutes. Based on the participants' preference, we actively moderated and facilitated conversations and discussions.

Following participatory principles (e.g., Brydon-Miller et al., 2011), the team codeveloped and revised the interview/topic guide during cycles of reflection between the focus groups. The guide was intended to encourage conversations about meeting places based on the following topics: the experience of simply 
being in meeting places; perspectives on 'service use' (first-hand knowledge, involvement and difference); being accepted and rejected in meeting places as compared with civil society; and interrelations of meeting places and the surrounding community and society.

\section{Discourse analysis}

One of the co-researchers transcribed the audio-recorded focus group interviews verbatim. The participants' anonymity and integrity were protected in the transcriptions. We translated the quotations used in the current article from raw transcriptions with Norwegian dialects to a written English format in which we sought to limit transcription code and less relevant noise and interruptions to increase reader-friendliness. We show some transcription code to keep the quotations verbatim, such as underlining emphasised words in a sentence and marking irony with italics. In some instances, it was necessary to compress longer elaborations to include aspects of the full storyline. The reduction of noise and speech compression is indicated by three ellipses (...).

An important early step in Parker's (2014/1992) outline of discourse analysis is to locate discursive constructions of relevant objects and subjects in a text (i.e., how subjects and objects are spoken of and produced in the text). The discursive constructions are then analysed as related to broader discourses. Parker's guidance is based on seven criteria and three auxiliary criteria that can be utilised to reconstruct the contours of discourses and their workings. These criteria entail (1) tracing textually (2) coherent systems of meaning (3) that construct certain discursive objects and (4) position subjects and are (5) located in history and sociocultural space. Discourses can be traced to reflect on (6) other discourses and (7) themselves and to be implicated with (i) societal institutions, (ii) power relations and (iii) ideological effects (Parker, 2014/1992, pp. 3-22).

In accordance with participatory research traditions (Borg \& Kristiansen, 2009), we arranged several capability-building seminars; in one of them, the aim was to facilitate what we have called participatory discourse analysis. The primary analysis team (co-researchers and first author) had access to the transcripts and suggested particularly interesting sections for discourse analysis in collaborative workshops. Two analytic strategies guided our collaborations: (a) we formed free associations with words and segments of the sections, relating them to social phenomena and ideas on a path to identifying preliminary traces of discourses, in line with Parker's guidance; and (b) we collectively engaged in a speed analysis of a section with as many of Parker's criteria as possible in the timeframe of a workshop.

The first author engaged in an analysis of the full material. Because the full material was extensive, the first author started by engaging in a preliminary analysis using Parker's 10 criteria and the analytic work from the participatory workshops, where relevant, while consecutively reading each transcript. The different suggestions for discursive constructions of meeting places were gathered and grouped. The constructions were scrutinised for accountability in relation to the material, the surrounding society and service users. The preceding steps built the foundation for a thorough analysis of each of the discourses that meeting places were identified as drawing on, the subjects and the discourses' sociohistorical ties. To enable a more nuanced analysis of the discursive constructions and discourses of meeting places and the surrounding civil society, the full research team reflexively reviewed the preliminary analysis in cycles. 


\section{Analysis}

\section{Sanism in civil society}

'Pull yourself together!' This comment was discussed as something commonly said to service users by people without service user experiences. Such comments were discussed as making things worse, as 'Kristie's' passage below illustrates. We read the participants' laughs and sarcasm as emphasising the ridiculousness of such comments.

Kristie: ... If you have hurt your hand or ... foot or something else that people can see ... Right. But, what's in our hearts and up here [head] ... people cannot [see], so when people say, 'Oh my goodness, you have to pull yourself together now' ... Interviewers and participants: Mm, Yes, That's right [endorsing comments interrupting throughout].

Kristie: Right?

Interviewer L: It's not that helpful [chuckles].

Kristie: No, it isn't!

Audrey: [laughs]

Patrick: It's not possible! It's not possible!

Kristie: It actually makes things kind of worse.

Audrey: Just try it! [chuckles]

Interviewer L: Yes.

Joel: Yes, that's right.

Kristie: Because you so sincerely want to 'pull yourself together', right, but you cannot control it.

Here, we see the contours of a discourse of sanism in which people positioned as mentally ill appear to be blamed for not trying hard enough to emerge from their struggle. Furthermore, they seem to be positioned as not knowing their own best interests, while the versions of reality of people positioned as sane are systematically privileged, allowing for paternalising corrections.

Although we observed glimpses of sanism in talk related to meeting places' spaces, sanist exclusions were discussed as worse in civil society outside of meeting places. We view 'Anna's' following statement as an example of how pronounced the experience of sanist exclusion from civil society could be: 'It feels like the walls surrounding people with mental health problems are moving from the institutions out to civil society'.

Sanism was discussed as especially tangible in attempts at interactions with civil society, as described by 'Joel', a man in his 50 s who lived in a rural municipality:

Joel: ... In the café ... I feel their gazes on my back, and...

Several service users: [endorsing, recognising]

Joel: I can hear them whispering in the background.

Several service users: [endorsing, recognising]

June: Oh, that's so painful! 


\section{Discursive constructions of meeting places}

\section{i) Public welfare arrangement}

A central construction of meeting places was as a public welfare arrangement for service users who have been excluded from civil society and the labour market. Traces of this construction can be read in this excerpt by 'Nicholas', who discussed having been bullied during childhood and at his place of work, culminating in being pushed into a disability pension after he was diagnosed with a chronic disease:

Nicholas: And then I thought, when I got it, that there wasn't anything [left] ... it became a very monotonous life. But, after many years with different experiences, then it came to my homestead, this, this service.

Interviewer L: Your meeting place.

Nicholas: ... And then I have a place to go because I always make sure to get myself out the door ... and it is important to me. Because then, then you have some kind of purpose. But, I didn't the first years, nothing was in place then.

As alluded to above, meeting places appeared to be constructed as compensating for some qualities of work life, such as having a purpose to get out every day, and as possibly providing service users the opportunities to feel like contributing citizens who belong in society. As such, we traced the contours of a social democratic welfare discourse, which could be described as institutionalised solidarity to facilitate every citizen being ensured social rights and opportunities to live a good life (Brandal et al., 2013).

The public welfare arrangement and professionally employed staff were portrayed as irreplaceable in the everyday lives of many users. Staff bore the formal responsibility for ensuring that everyone was included and cared for and were also responsible for organising and facilitating many routines and activities. This seemed related to the shortcomings of civil society and the situation of people positioned in distress who were described as already working hard 'just' to keep their heads above water. However, meeting places as welfare arrangements were not without dilemmas. Service users could be positioned as passive objects to other people's ends, such as staff's work and fellow service users' social needs.

Service users were, nevertheless, also positioned as equal citizens in setting agendas and working towards facilitating their needs and social rights through service user involvement. Staff members were positioned as not always 'liking' the demands of service users but still accepting of democratic decisions. Both in the current analysis of service users' accounts and in the study based on staff accounts (Ynnesdal Haugen et al., 2016), concerns were raised about the future of public welfare arrangements with regard to economic matters.

\section{ii) Peer community}

We also reconstructed meeting places as a peer community inhabited by people who understand and accept each other and share a distaste for sanism, as 'June's' account demonstrates:

June: You go free of having to sit and say, 'Yes, I'm on disability pension, I was put on disability pension over 20 years ago'. 'You're on disability pension?', and ... 'Just for mental health problems?' ... Then, it's good to be with people who know that there is no such thing as just mental health problems ... 
As illustrated through June's account above and 'Wilma's' account below, we discerned the contours of a discourse of solidarity among service users:

Wilma: ... But, once you've made your way over it [the high doorstep] and make it to a centre, or ... yeah, we call it a day centre ...

Interviewer L: Mm.

Wilma: - and meet peers-you could be depressed and out of it, but when you get inside and meet 'the gang', as I call them-and we talk and stuff, then, yeah-it lets go.

Service user: Lets go.

[Ongoing interruptions with endorsing comments while Wilma talks]

Wilma: So, not always, like-it's not some kind of miracle cure, but it really helps. And to get to talk with others with-who are in the same situation as you

Service user: To socialise.

Wilma: -without sitting talking about the disease, but you know they understand ... that you have a bad day, right ... And many say what she [Ruth] says, that it's not that easy for family or others who aren't ill to understand ... Ruth: Not for those who work with it [either]. They say it themselves: 'We can't know what you're thinking on the inside' ...

As traced through Wilma's account, a discourse of solidarity among service users appeared to position service users as those who implicitly know, share and accept each other's 'situation', identity, and interests in everyday life. Our analysis suggests that the peer community could imply exclusivity for people who self-identify as service users. Upholding belongingness to the peer community might, as such, imply being delimited to a 'service user identity' and, thus, constitute a form of dependency.

This said, outsiders to the peer community, including mental health professionals, were positioned as lacking understanding of service users' lived situations and also being implicated in exacerbating their burdens, as discussed by 'Ruth' below:

Ruth: ... As bad of shape as I was in when I got out of the [mental] hospital, and ... the level of critique I was faced with all the time, bombarded with [for not 'pulling herself together'] then, I would have turned mad if I hadn't had the meeting place to go to ...

\section{iii) Spaces of compassion}

In meeting places constructed as spaces of compassion, service users encountered care and validation. As discussed by 'Trudy' below, spaces of compassion could even be viewed as saving lives:

Trudy: I believe I can at least say that I believe that these activity centres have saved many lives.

Loretta: Yes.

Interviewer L: Yes.

Trudy: I believe I can honestly say so.

Loretta: I absolutely agree with you.

Interviewer L: Yes.

Trudy: They have saved many lives!

Loretta: Yes, yes.

Trudy: And for sure, one life, just one life is precious, extremely precious ...

We traced accounts such as this to draw on a discourse of compassion in which life is unconditionally valued and recognised in its own right. The people who worked in such places appeared to be positioned as compassionate carers, 
even saviours, who helped people live a fuller life, as 'Molly's' quotation below testifies:

Molly: I could [leave the house] before, but ehm, after the rape and everything, I wasn't able to ... Now, I turn off the lights when I'm home by myself, and it's dark ... So, if it hadn't been for the ladies [staff] down there [meeting place], l'd be sitting at home...

Carers were also positioned to help people on their own terms, as in the following passage by 'Frank':

Frank: ... In the beginning, I could contact her ten times during the day ... Now ... I call if I need to ... To be that patient. I bombarded her with text messages in the middle of the night, it didn't matter ... And such a good person. It's incredible that there are people working in a municipality who are so dedicated to their work ... Far beyond the job requirements ...

The continued positioning of service users as being in need of help could, nevertheless, limit their movement away from a disempowered help-seeking position. However, service users were also positioned as possible carers, whose care could be especially warming after they found their footing. This might imply that acts of kindness extending beyond the self-interests of a carer, such as 'job requirements', could position the carer as a fellow human being rather than, for instance, an 'employee' of a service. As such, a service user encountering a carer's compassion might be positioned as a human being worthy of the compassion of another human being.

\section{iv) Greenhouses}

Meeting places were also reconstructed as inhabiting various spaces that resembled greenhouses, in that they facilitated growth conditions for people attending meeting places. Greenhouses appeared to help people explore the world and themselves and to expand their constructions of personhood and horizons of possibility. We view this construction as drawing on a humanist developmental discourse, which is traced to involve bringing out the best in people ('self-actualisation') based on self-directed and self-determined transformations and people's inner potentials. As 'Audrey' and 'Patrick' discussed in the following excerpt, freedom of movement could be reconstructed to facilitate transformations:

Audrey: ... My friend 'Christina' ... has really grown ... with her ... artistic side ... And she's having an art exhibit now ... and she has amazing paintings. Patrick: Yes, she has.

$\cdots$

Audrey: [Christina] is someone who has blossomed without anyone pressuring her

[voice cracks, touched].

Two service users: $\mathrm{Mm}, \mathrm{mm}$ [endorsing].

Audrey: No pressure/don't press [dual meanings, soft whisper].

Patrick: To the contrary, they've [staff] let her [grow] ... with kindness and ...

Warmth ... so she ... just like the porcupine ...

Audrey: [Chuckles]

Patrick: ... awakens from hibernation ... and like has become a blossoming person. Instead of a person just sitting there not knowing ...

Within this discourse, the last sentence might imply that individual change appears not only possible but also preferable. This could limit the range of possibilities for service users to just be. Following Mad studies (LeFrancois et al., 2013), working for societal acceptance, rather than seeking to change 
people with psychosocial differences, should be a central concern for service users' movements. Nevertheless, the discussed change processes appeared to be constructed as being directed by the person's self-determined needs and pace. In contrast, normative developmental pressures, such as becoming a 'productive citizen', were discussed as limiting rather than facilitating transformations. Still, meeting places could be reconstructed as expanding the horizons of possibility concerning people's livelihoods, such as Christina's art exhibit.

Moreover, the humanist developmental discourse appeared to position staff as facilitating many of the conditions of possibility for transformations through being there, being ready to see even small glimmers of something to build on and providing support, as 'Caroline' described:

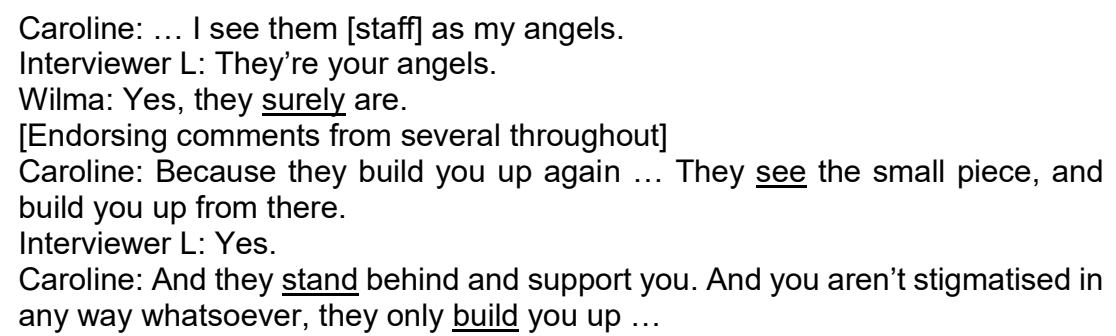

\section{Discussion}

Generally, our analysis of service users' accounts of meeting places appears to align with much of the reviewed literature in contouring meeting places' importance in the everyday lives of the people who attend them. Our analysis also resonates with the literature regarding the rejection and exclusion experienced in civil society by many people in psychosocial hardship (e.g., Elstad \& Eide, 2009; Hall \& Cheston, 2002; Larsen \& Topor, 2017; Pinford, 2000).

As indicated in the introduction, problematizations of meeting places exist. A recent analysis of house rules in sheltered houses and meeting places in a Norwegian city noted that the house rules may reproduce criticized institutional practices and identities for persons with mental illnesses and substance abuse problems (Andersen, Larsen \& Topor, 2016). Also, studies about staffed meeting places in terms of well-being and functioning of users are not clear-cut (e.g., Eklund, Hansson, \& Ahlqvist, 2004; Eklund \& Sandlund, 2014). Such problematizations relate to a pronounced objection-that people become passive objects of service provision, obscured from participating in the labour market and mainstream society (e.g., Social Exclusion Unit, 2004). We will discuss the findings in light of aspects of this objection. We organize this around the four central discursive constructions of meeting places identified in the analysis section, and we will keep an eye to the practical and real-life consequences for users of meeting places.

\section{i) Compensatory public welfare arrangement positioning service users as citizens with social rights}

Our analysis, as well as an inquiry by Bryant et al. (2004), has identified occurrences where people attending meeting places were described as objects of service provision. However, in our analysis, such objectifications stood out as unintended consequences of meeting places constructed as staffed welfare 
arrangements that seemed to compensate for exclusion from the labour market and civil society. Through our analysis of a social democratic discourse, meeting places and staff appeared to embody the universal principle by providing opportunities for social rights to a good life and the materialisation of such rights.

As discussed in the literature (e.g., Hall \& Cheston, 2002), our analysis suggests that civil society does not seem to be particularly inclusive towards people who are psychosocially different from the normativity of sanity, which is also in line with Mad studies (Chamberlin, 1990; LeFrancois et al., 2013). In our focus groups, people described sanist comments and questions as resembling demands to legitimise one's psychosocial hardships and entitlements to welfare benefits, implying that there were pressures towards becoming a productive citizen.

In this article, and based on staff accounts (Ynnesdal Haugen et al., 2016) in another article from the same project, service users were positioned as defending staffed meeting places and resisting pressures for responsibilisation. In short, responsibilisation could be described as a neoliberal process in which, for instance, state responsibility becomes viewed as the responsibility of individuals (O'Malley, 2009). The objections regarding meeting places could suggest the presence ofresponsibilisation by placing the responsibility for lower employment rates on people attending meeting places rather than viewing the unavailability of sustainable work and social acceptance of their differences as larger-scale social, economic and political matters. In this analysis and in, for instance, Elstad and Eide's (2009) and Pinford's (2000) ethnographic studies, added pressure in addition to the hard work of keeping one's head above water was described as entailing even heavier tolls, possibly with implications of increased hardship. This is, however, nuanced by studies suggesting that there appears to be a pattern of differing preferred occupations among users. Some users in greater distress preferred to just be in the meeting place while others preferred to engage in more task-orientated occupations that were increasingly demanding (Argentzell, Håkansson, \& Eklund, 2012; Horghagen, Fostvedt, \& Alsaker, 2014; Tjörnstrand, Bejerholm, \& Eklund, 2011).

\section{ii) Peer community positioning service users as peers who share common identities and interests}

One of the most predominant discursive constructions of meeting places in the focus group conversations was a peer community, described as a group of people who implicitly know distress, hardships and sanism. The significance and support of a peer community is discussed across studies inside and outside of meeting places (e.g., Andvig \& Hummelvoll, 2016; Hall \& Cheston, 2002; Larsen \& Topor, 2017). We located a peer community in a discourse of solidarity among peers, drawing on ideas and values in the interests of service users and interrelated with service users' movements that have been gaining momentum since the late 1970s (Chamberlin, 1990). Following our analysis, a peer community appeared to facilitate spaces for being temporarily 'freed' from distress and sanist demands. This aligns with Bachke and Larsen (2017), who point to a possible need for a society within the society for this group. Thus, in relation to a potential 'dependency' on the peer community and to objections raised regarding participation in mainstream society (Social Exclusion Unit, 2004), engaging in such spaces appears more appealing than engaging with a sanist civil society. 


\section{iii) Spaces of compassion validating service users as fellow human beings who are precious in their own right}

As a related topic, possibilities for just being in meeting places were analysed as being particularly facilitated by spaces of compassion and were localised in a discourse of compassion. Here, service users were positioned as worthy of being accepted as a fellow person by other human beings without needing to do anything to earn it. Space for service users to just be stands in stark contrast to local and global neoliberal production demands (Harvey, 2005; Hedegaard, 2016).

Altogether, the discourses of social democracy, solidarity and compassion appeared to facilitate spaces where productivity pressure is reduced while users are taking part in society by simply being with others who accept and understand them. In line with our analysis, reconstructing the hard work that could go into staying afloat at times of distress and the identification of a need for reduced pressure during distress also appear to resonate with the reviewed literature (e.g., Bryant et al., 2004; Elstad \& Eide, 2009; Larsen \& Topor, 2017; Rise, Westerlund, Bjørgen, \& Steinbekk, 2013; Tjørnstrand et al., 2011).

\section{iv) Greenhouses facilitating service users to expand their horizons of possibility}

In our analysis of greenhouses, located in a discourse of developmental humanism, the staff of meeting places appeared to provide support to the person when the person was ready to expand his horizons of possibility without normative pressuring. According to the literature, times of less distress seemed related to greater interest in self-determination and engagement in occupations (e.g., Horghagen et al., 2014; Rise et al., 2013).

The literature's critique of service users being made into passive objects in need of help (Social Exclusion Unit, 2004) was also noted in our analysis of a discourse of compassion. However, our analysis also delineates that supportive spaces to just be - with reduced external pressure and being temporarily freed from distress - appeared important to accommodate the person in acquiring expendable capacity after the work needed for keeping one's head above water and in venturing into expanding her horizons of possibility when ready and able. This is in line with an analysis and discussion of meeting places based on dialogues with users of a meeting place in southern Norway (Larsen, 2015). Here, it is emphasized that it is important to establish an atmosphere of inclusion and equality.

In relation to the objections regarding meeting places, our discussion suggests that reducing rather than increasing civil society pressures seemed to be in the interest of people in distress.

\section{Limitations}

Although we inquired about problematic aspects of meeting places, few were addressed in the focus groups. This might be due to a potential disadvantage with focus group interviews, where persons identifying with each other may quiet their dissent (Malterud, 2012). However, in an era of rising neoliberalism and reductions in welfare services (Fjellfeldt et al., 2016; Hedegaard, 2016), limited problematisation could also be related to concerns raised by several service users in this inquiry and in other inquiries regarding the future of staffed meeting places (e.g., Andersson et al., 2016; Elstad \& Eide, 2009). As a 
community psychology and participatory inquiry, we consider it to have resonated with our aims that we have taken this threat seriously and sought to benefit the people our inquiry could affect (e.g., Fine, 2012; Nelson et al., 2001).

In line with Parker's (2014/1992) discussions, the participatory discourse analysis we have detailed here presents only one possible discursive reading of the material and is intertwined with our team's sociocultural positioning as Norwegians and as persons with first-hand and academic knowledge of psychosocial hardships. Given that language is here understood as an open system, other readers can and will analyse the material differently (Parker, 2014/1992)

Furthermore, this article touches upon historical relations of the analysed discourses only to a limited extent, despite the importance of history in Foucauldian discourse analysis (Parker, 2014/1992). Nevertheless, we still view as legitimate our collectively reached decisions to focus on the discourses' present forms and implications for people attending meeting places. We consider the decisions to be legitimate given the tenets of qualitative research that emphasise that every analysis is unique and necessitates critical and reflexive tailoring of one's lenses and craft (Denzin \& Lincoln, 2011).

Another potential limitation is that discourse analysis, as a complex methodology, could have limited the co-researchers' participation in the analytic process. However, through our many hours of negotiations and constructive disagreements in the analytic process, we consider that we have co-constructed the analysis and our version of participatory discourse analysis.

While the purpose of the current analysis was to study 'how service users discuss their encounters with the spaces and people of meeting places', quite another line of inquiry is to study the effects of meeting places on meaningfulness and well-being (e.g., Eklund et al., 2004). Related to such alternative research questions, there is a need for methodologies other than discourse analysis (e.g., validated questionnaires; see Nilsson, Argentzell, Sandlund, Leufstadius, \& Eklund, 2011). Future in-depth studies within the field might even combine research questions encompassing discourses, experiences and effects, thus necessitating a variety of methodologies.

\section{Conclusion}

This participatory discourse analysis of service users' accounts of meeting places, together with the reviewed literature, implies that meeting places could mean everything to the people who attend them by facilitating opportunities that were discussed as being less accessible elsewhere in their everyday lives (e.g., Horghagen et al., 2014; Pinford, 2000). Until ordinary civil society can offer people in psychosocial hardships opportunities similar to staffed meeting places, our inquiry suggests that meeting places appear to be in the interest of the people who attend them.

\section{References}

Andersen, A. J. W., Larsen, I. B., \& Topor, A. P. (2016). Caring through discipline? Analyzing house rules in community mental health services in Norway. Scandinavian Psychologist, 3(e1). https://doi.org/10.15714/scandpsychol.3.e1

Andersson, M., Eklund, M., Sandlund, M., \& Markström, U. (2016). Freedom of choice or cost efficiency? The implementation of a free-choice market system in

NJSR - Nordic Journal of Social Research 
community mental health services in Sweden. Scandinavian Journal of Disability Research, 18, 129-141. https://doi.org/10.1080/15017419.2014.995220

Andvig, E., \& Hummelvoll, J. K. (2016). 'I dare': Experiences of young adults at risk participating in a one-year inclusive-theater project in Norway. Nordic Journal of Social Research, 7. https://doi.org/10.15845/njsr.v7i0.873

Argentzell, E., Håkansson, C., \& Eklund, M. (2012). Experience of meaning in everyday occupations among unemployed people with severe mental illness. Scandinavian Journal of Occupational Therapy, 19(1), 49-58. https://doi.org/10.3109/11038128.2010.540038

Argentzell, E., Leufstadius, C., \& Eklund, M. (2012). Factors influencing subjective perceptions of everyday occupations: Comparing day centre attendees with nonattendees. Scandinavian Journal of Occupational Therapy, 19, 68-77. https://doi.org/10.3109/11038128.2011.560963

Bachke, C. C., \& Larsen, I. B. (2017). Fra behandling til recovery. En review-studie av forskning på dagsenter for mennesker med psykiske lidelser [From treatment to recovery. A literature review of research on day centers for people with mental health problems]. Nordisk Tidsskrift for Helseforskning, 13(2). https://dx.doi.org/10.7557/14.4213

Bergem, R., \& Ekeland, T. J. (2006). Citizenship of people with mental illness [only in Norwegian]. Tidsskrift for Velferdsforskning, 9, 26-38.

Borg, M., \& Kristiansen, K. (Eds.). (2009). Medforskning: Å forske sammen for kunnskap om psykisk helse [Service user involvement in research: Doing research together for knowledge about mental health]. Oslo, Norway: Universitetsforlaget.

Brandal, N., Bratberg, Ø., \& Thorsen, D. E. (2013). The Nordic model of social democracy. London, UK: Palgrave Macmillan. https://doi.org/10.1057/9781137013279

Bryant, W. (2011). Mental Health Day services in the United Kingdom from 1946 to 1995: An 'untidy set of services'. The British Journal of Occupational Therapy, 74, 554561. https://doi.org/10.4276/030802211X13232584581371

Bryant, W., Craik, C., \& McKay, E. A. (2004). Living in a glasshouse: Exploring occupational alienation. Canadian Journal of Occupational Therapy, 71, 282-289. https://doi.org/10.1177/000841740407100507

Brydon-Miller, M., Kral, M., Maguire, P., Noffke, S., \& Sabhlok, A. (2011). Jazz and the Banyan tree. Roots and riffs on participatory action research. In N. K. Denzin, \& Y. S. Lincoln (Eds.), The Sage handbook of qualitative research (4th ed., pp. 387400). Thousand Oaks, CA: Sage.

Catty, J. S., Burns, T., Comas, A., \& Pool, Z. (2008). Day centres for severe mental illness (review). The Cochrane Library, 3, 1-16. https://doi.org/10.1002/14651858.CD001710.pub2

Chamberlin, J. (1990). The ex-patients' movement: Where we've been and where we're going. The Journal of Mind and Behavior, 11, 323-336.

Dencker-Larsen, S., \& Lundberg, K. G. (2016). Depicted welfare-recipient stereotypes in Norway and Denmark: A photo-elicitation study. Nordic Journal of Social Research, 7. https://doi.org/10.7577/njsr.2098

Denzin, N. K., \& Lincoln, Y. S. (2011). Introduction. In N. K. Denzin, \& Y. S. Lincoln (Eds.), The Sage handbook of qualitative research (4th ed., pp. 1-19). Thousand Oaks, CA: Sage. 
Ekeland, T. J., Stefansen, J., \& Steinstø, N. O. (2011). Clinical autonomy in the era of evidence. Governmental challenges for clinical practice. Tidsskrift for Velferdsforskning, 14(1), 2-14.

Eklund, M., Hansson, L., \& Ahlqvist, C. (2004). The importance of work as compared to other forms of daily occupations for wellbeing and functioning among persons with long-term mental illness. Community Mental Health Journal, 40(5), 465-477. https://doi.org/10.1023/B:COMH.0000040659.19844.c2

Eklund, M., \& Sandlund, M. (2014). Predictors of valued everyday occupations, empowerment and satisfaction in day centres: Implications for services for persons with psychiatric disabilities. Scandinavian Journal of Caring Sciences, 28(3), 582-590. https://doi.org/10.1111/scs.12085

Eklund, M., \& Tjörnstrand, C. (2013). Psychiatric rehabilitation in community-based day centres: Motivation and satisfaction. Scandinavian Journal of Occupational Therapy, 20(6), 438-445. https://doi.org/10.3109/11038128.2013.805428

Elstad, T. A., \& Eide, A. H. (2009). User participation in community mental health services: Exploring the experiences of users and professionals. Scandinavian Journal of Caring Sciences, 23, 674-681.https://doi.org/10.1111/j.1471$\underline{6712.2008 .00660 . x}$

Evans-Lacko, S., Knapp, M., McCrone, P., Thornicroft, G., \& Mojtabai, R. (2013). The mental health consequences of the recession: Economic hardship and employment of people with mental health problems in 27 European countries. PLoS One, 8, e69792. https://doi.org/10.1371/journal.pone.0069792

Fine, M. (2012). Troubling calls for evidence: A critical race, class and gender analysis of whose evidence counts. Feminism \& Psychology, 22, 3-19. https://doi.org/10.1177/0959353511435475

Fjellfeldt, M., Eklund, M., Sandlund, M., \& Markström, U. (2016). Implementation of choice from participants' perspectives: A study of community mental healthcare reform in Sweden. Journal of Social Work in Disability \& Rehabilitation, 15(2), 116-133. https://doi.org/10.1080/1536710X.2016.1162121

Foucault, M. (1988). Madness and civilization: A history of insanity in the age of reason (R. Howard, Trans.). New York, NY: Vintage Books. (Original work published 1961)

Hall, S., \& Cheston, R. (2002). Mental health and identity: The evaluation of a drop-in centre. Journal of Community \& Applied Social Psychology, 12, 30-43. https://doi.org/10.1002/casp.639

Hamre, B., Fristrup, T., \& Christensen, G. (2016). The subject of exemption: Through discourses of normalization and individualization in Denmark. Nordic Journal of Social Research, 7. https://doi.org/10.15845/njsr.v7i0.899

Harvey, D. (2005). A brief history of neoliberalism. Oxford, UK: Oxford University Press.

Hedegaard, T. F. (2016). Neo-liberalism and the Nordic welfare model: A study of the liberal alliance and ideological adaptation in Denmark. Nordic Journal of Social Research, 7. https://doi.org/10.7577/njsr.2099

Horghagen, S., Fostvedt, B., \& Alsaker, S. (2014). Craft activities in groups at meeting places: Supporting mental health users' everyday occupations. Scandinavian Journal of Occupational Therapy, 21, 145-152. https://doi.org/10.3109/11038128.2013.866691

Kalseth, J., Pettersen, I., \& Kalseth, B. (2008). Psykisk helsearbeid i kommunene - tiltak og tjenester. Status 2007/2008 og utvikling i Opptrappingsplanperioden.

NJSR - Nordic Journal of Social Research 
[Community mental health care in municipalities - initiatives and services. Status 2007/2008 and developments in the Action Plan period] (SINTEF report A8823). Trondheim, Norway: SINTEF. Retrieved from http://www.sintef.no

Larsen, I. B. (2015). Dialogiske omgivelser som betydningsfulle for mennesker med psykiske problemer. 'Vi blir friskere av å gå her' [Dialogical environments as significant for people with psychological problems. 'We become healthier from attending this place']. In D. Ulland, A. B. Thorød, \& E. Ulland (Eds.), Psykisk helse. Nye arenaer, aktører og tilnærminger (pp. 30-37). Oslo: Universitetsforlaget.

Larsen, I. B., \& Topor, A. (2017). A place for the heart: A journey in the post-asylum landscape. Metaphors and materiality. Health and Place, 45, 145-151. https://doi.org/10.1016/j.healthplace.2017.03.015

LeFrancois, B. A., Menzies, R., \& Reaume, G. (Eds.). (2013). Mad matters: A critical reader in Canadian mad studies. Toronto, Canada: Canadian Scholar's Press Inc.

Malterud, K. (2012). Fokusgrupper som forskningsmetode for medisin og helsefag [Focus groups as a research method for medicine and health sciences]. Oslo: Universitetsforlaget.

Mattheys, K. (2015). The coalition, austerity and mental health. Disability \& Society, 30 , 475-478. https://doi.org/10.1080/09687599.2014.1000513

Ministry of Health and Care Services. (1998). Om opptrappingsplan for psykisk helse 1999-2006. St.prp. nr. 63 (1997-98). [Report No. 63 to the Storting (1997-1998) on the Escalation plan for mental health 1999-2006]. Oslo, Norway: Ministry of Health and Care Services.

National Social Inclusion Programme. (2008). From segregation to inclusion: Where are we now? A review of progress towards the implementation of the Mental Health Day services commissioning guidance. London, UK: National Inclusion Programme.

Nelson, G., Prilleltensky, I., \& MacGillivary, H. (2001). Building value-based partnerships: Toward solidarity with oppressed groups. American Journal of Community Psychology, 29, 649-677. https://doi.org/10.1023/A:1010406400101

Nilsson, I., Argentzell, E., Sandlund, M., Leufstadius, C., \& Eklund, M. (2011). Measuring perceived meaningfulness in day centres for persons with mental illness. Scandinavian Journal of Occupational Therapy, 18(4), 312-320. https://doi.org/10.3109/11038128.2010.522592

Norwegian Council for Mental Health. (1995). Velferdsstatens forsømte gruppe [The neglected group of the welfare state]. Oslo: The Norwegian Council for Mental Health. Retrieved from http://www.nb.no/nbsok/nb/da967be511dbc872a612f7f5d3add109.nbdigital?lan $\mathrm{g}=\mathrm{no} \# 6$

Norwegian Directorate of Health. (2005). Veileder. Psykisk helsearbeid for voksne i kommunene [Guidance. Community mental health care for adults in the municipality]. Oslo, Norway: Norwegian Directorate of Health.

O'Malley, P. (2009). Responsibilization. In A. Wakefield \& J. Fleming (Eds.), The SAGE dictionary of policing (pp. 277-279). London, UK: SAGE Publications Ltd. https://doi.org/10.4135/9781446269053

Osborg Ose, S., \& Slettebak, R. T. (2012). Kommunale tiltak i psykisk helsearbeid 2012. Arsverksstatistikk og analyser av kommunal variasjon [Municipal activity in community mental health care 2012. Statistics on full time equivalents and 
analyses of municipal variations]. (SINTEF report No 60H215/ 102001067). Trondheim, Norway: SINTEF. Retrieved from http://www.sintef.no

Parker, I. (2014). Discourse dynamics: Critical analysis for social and individual psychology. London: Routledge. (Original work published in 1992)

Pinford, V. (2000). 'Building up safe havens...all around the world': Users' experiences of living in the community with mental health problems. Health \& Place, 6, 201 212. https://doi.org/10.1016/S1353-8292(00)00023-X

Rise, M. B., Westerlund, H., Bjørgen, D., \& Steinbekk, A. (2013). Safely cared for or empowered in mental health care? Yes, please. International Journal of Social Psychiatry, 60, 134-138. https://doi.org/10.1177/0020764012471278

Social Exclusion Unit. (2004). Mental health and social exclusion. Social Exclusion Unit report. Retrieved from http://hdl.handle.net/10822/1039428

Tjörnstrand, C., Bejerholm, U., \& Eklund, M. (2011). Participation in day centres for people with psychiatric disabilities: Characteristics of occupations. Scandinavian Journal of Occupational Therapy, 18, 243-253. https://doi.org/10.3109/11038128.2011.583938

Ynnesdal Haugen, L. S., Envy, A., Borg, M., Ekeland, T. J., \& Anderssen, N. (2016) Discourses of service user involvement in meeting places in Norwegian community mental health care: A discourse analysis of staff accounts. Disability \& Society, 31(1-2), 1-18. https://doi.org/10.1080/09687599.2016.1139489 